\title{
Al-Zn 合金の組成と諸特性
}

\author{
稲葉達一*，秋園幸一**，紅露孝哉***，大島宏之****

\section{On the Relation between Compositions of Al-Zn Alloys and Their Characteristics}

\author{
Tatsuichi INABA*, Koichi AKIZONO**, Koya KORO*** and Hiroyuki OSHIM A****
}

\begin{abstract}
Eight kinds of $\mathrm{Al}-\mathrm{Zn}$ alloys with $\mathrm{Zn}$ concentrations ranging from 5.5 to $94 \mathrm{wt} \%$ were made on a laboratory scale. Measurements of certain mechanical properties in the atmosphere and of corrosion potentials in $3 \% \mathrm{NaCl}$ solution, as well as surface composition analysis were carried out on as-cast ingots of the above alloys. It was concluded that the alloy containing $32 \mathrm{wt} \% \mathrm{Zn}$ had peculiar properties. Key Words : Al-Zn Alloy, Equilibrium Phase Diagram, Mechanical Property, Corrosion Potential, Surface Composition Analysis
\end{abstract}

\section{1. 緒言}

$\mathrm{Al}-\mathrm{Zn}$ 系合金は，その使用量や使用分野の增大が予想 されているにもかかわらず，実用材料としては，例衤ば 7000 番台 $\mathrm{Al}$ 合金（数\% $\mathrm{Zn}$ ) 执よびダイキャスト用 $\mathrm{Zn}$ 合金（数\% Al）などのように, Al-rich 側叔よび Znrich 側での使用が多い。最近, 積極的な $\mathrm{Al}$ 合金の需要 の開拓や重力鋳造用 $Z n$ 合金の開発拈よび $\mathrm{Al}-Z \mathrm{n}$ 合金 の溶射への適用などが図られるようになり，Al-Zn系合 金の広い組成範囲にわたる利用が現実的に考穴られるよ らになった。

上述のことから，現用されている $\mathrm{Al}-\mathrm{Zn}$ 合金の組成 や $\mathrm{A} 1-\mathrm{Zn}$ 二元合金状態図に括ける共晶や共析などの状 態図的な特徵を考虑して，8 種類の $\mathrm{Al}-\mathrm{Zn}$ 合金を溶製 し, 機械的性質（引張強さ，耐力，伸び抢よび硬さ）や 自然腐食電位特よび表面組成分析などを行い，若干の知 見を得たので報告する。

* 德島大学工学部 ( 7770 徳島県徳島市南常三島町2-1) Fac. of Eng., The Uni. of Tokushima (2-1, Minami Josanjima-cho, Tokushima-shi, Tokushima 770)

** 德島大学工学部 (現: 徳島文理大学) (テ770 徳島県徳 島市南常三島町2-1)

Fac. of Eng., The Uni. of Tokushima (Present : Tokushima Bunri University) (2-1, Minami Josanjima-cho, Tokushima-shi, Tokusima 770)

*** 阿南工業高等専門学校（干774 德島県阿南市見能林町青 木)

Anan College of Technology (Aoki, Minobayashi cho, Anan-shi, Tokushima 774)

**** 光洋精工秼（干542 大阪府大阪市南区鰻谷西之町 2 ）

Koyo Seiko Co., Ltd. (2, Unagidani Nishino-cho, Minami-ku, Osaka-shi, Osaka 542)

\section{2. 実 験 方 法}

市販の高純度 $\mathrm{Al}(99.99 \%)$ とn( $99.99 \%)$ をアルラ るつぽとフラックスを使用して大気溶解し，鋳込及後の 分析值で $\mathrm{Zn}$ 濃度がそれぞれ5.5，15，32，50，62，78， 83 扰よび $94 \mathrm{wt} \%$ の 8 種類の板状 $(300 \mathrm{~mm} \times 30 \mathrm{~mm} \times$ $4 \mathrm{~mm})$ 抢よび丸棒状 $(15 \mathrm{~mm} \phi \times 50 \mathrm{~mm}) \mathrm{Al}-\mathrm{Zn}$ 合金鋳塊 を溶製した。鋳塊の溶製は, $720^{\circ} \mathrm{C}$ に $50 \mathrm{~h}$ 保持後, $\mathrm{Al}-$ $\mathrm{Zn}$ 合金状態図のそれぞれの組成に括ける液相線上約 40 ${ }^{\circ} \mathrm{C}$ から, 液相線下 $30^{\circ} \mathrm{C}$ に加熱して括いた板状金型と室温 の丸棒状金型の両者に鋳込むといら方法で行った。

板状鋳塊から機械加工によって引張試験片（長さ $130 \mathrm{~mm}$, 幅 $25 \mathrm{~mm}$, 平行部長さ $48 \mathrm{~mm}$, 平行部幅 $10 \mathrm{~mm}$ および厚さ $4 \mathrm{~mm}$ ）を切り出し，エメリー紙03番まで研 磨後, インストロン試験機によって引張試験を行い, 引 張強さ，耐力（ $0.2 \%$ 耐力）扣よび伸びを求めた。また， 板状拈よび丸棒状鋳塊のそれぞれの同一位置から，鋳塊 の横断面が出るように輪切り状に切り出し, エメリ一紙 05番からのバフ研磨後, Vickers 硬さ計で幅方向の硬さ を測定した。自然腐食電位は, エメリ一紙03番までの研 磨後, ポテンショメーターによって, $93^{\circ} \mathrm{C}$ (沸とう直 前) の $3 \% \mathrm{NaCl}$ 溶液中で, $50 \mathrm{~h}$ までの測定から求めた。 光学顕微鏡による組織観察は, ケラー氏液による腐食後, 100倍々 400 倍で行った。表面組成分析は, ケラー氏液に よる腐食によって現出した組織（白色部と黒色部）につ いて，1000倍の面分析像を参考にしながら，X線マイク ロアナライザーによって行った。

\section{3. 結果および考察}

図 1 は測定した機械的性質をまとめたものである。各 項目とも, $32 \% \mathrm{Zn}$ 付近に遷移点が認められる。この点 は, $\mathrm{Al}-\mathrm{Zn}$ 二元合金状態図によれば，共析変態が起る 


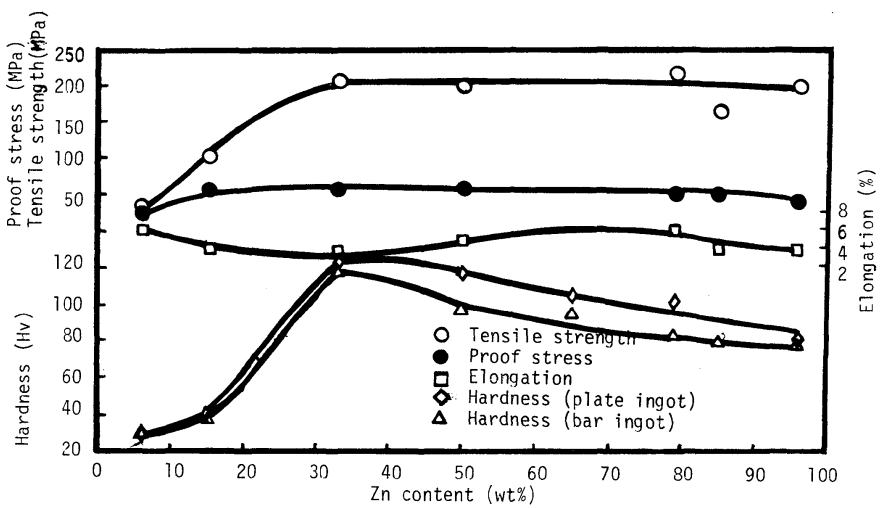

Fig. 1 Relation between some mechanical properties and $\mathrm{Zn}$ contents of as cast $\mathrm{Al}-\mathrm{Zn}$ alloys.

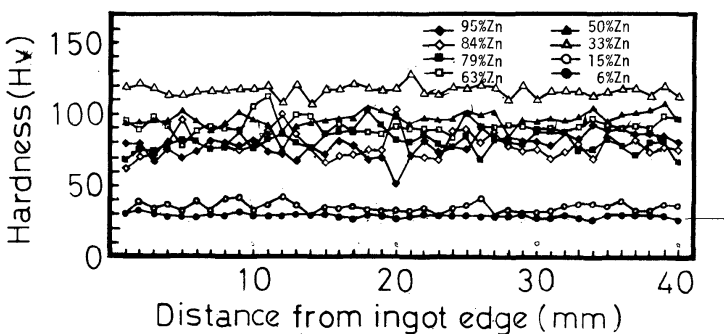

Fig. 2 Cross sectional hardness behaviors of as cast $\mathrm{Al}-\mathrm{Zn}$ alloy ingots.

組成に相当している。

図 2 は板状鋳塊の幅方向に拈ける硬さ挙動をまとめた ものである。 $6 \% \mathrm{Zn}$ が最小硬さを， $32 \% \mathrm{Zn}$ が最大硬 さをそれぞれ示しており, 硬さの順序とZn \%の順序と は一致していない。をた, それぞれの試験片に执いて, 同一平面内の硬さ分布はほぼ均一的であって, 平均值に 影響するほどの局部的な凹凸は認められない。

図 3 は自然腐食電位をまとめたものである。 $5.5 \%$ Zn, 15\% Zn 特よび $32 \% \mathrm{Zn}$ の順序で, $32 \% \mathrm{Zn}$ までは $\mathrm{Zn}$ 濃度の増大につれて腐食電位も貴になっている。 32 $\% \mathrm{Zn}$ 以上の $\mathrm{Zn}$ 濃度に打いては, $\mathrm{Zn}$ 濃度の増大にも かかわらず, 自然腐食電位はほとんど変化していない。 $32 \% \mathrm{Zn}$ 付近が $93^{\circ} \mathrm{C}$ の $3 \% \mathrm{NaCl}$ 溶液中での自然腐食電 位の遷移点になっていることがわかる。

X線マイクロアナライザーによる表面組成分析は主と して丸棒状鋳塊の中心部と端部とについて行った（デー タは省略, 参考文献参照 ${ }^{1}$ 。この両者とも, 黒色部よ りも白色部の方が Zn \%は高くなっている。また， $\mathrm{Al}$

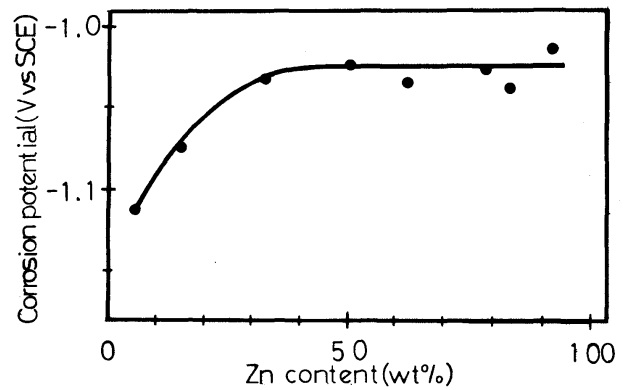

Fig. 3 Corrosion potentials of as cast $\mathrm{Al}-\mathrm{Zn}$ alloys in $3 \%$ $\mathrm{NaCl}$ solution at $93{ }^{\circ} \mathrm{C}$.

\%と $\mathrm{Zn} \%$ の比の関係が，白色部と黒色部の両者ともに, $32 \%$ 付近で反対(逆転)になっている。これらのことは機 峨的性質などとの関係を暗示しているように思われ，よ り詳細な研究が必要であろら。

\section{4. 結}

言

市販の高純度 $\mathrm{Al}$ と $\mathrm{n}$ 和よびフラックスを用いて， 実験室的に大気溶製した鋳ばなしのままの $\mathrm{Al}-\mathrm{Zn}$ 合金 について, 引張強さ, 酎力, 伸び, 硬さおよび腐食電位 の測定や表面組成分析などを行った。

$32 \mathrm{wt} \% \mathrm{Zn}$ を含む $\mathrm{Al}-\mathrm{Zn}$ 合金が特異的な挙動を示し た。

(1988-4-22 受理)

\section{文献}

1）稻葉達一，秋園幸一，紅露孝哉，大島宏之；金属表面技術 協会第76回講演大会講演要旨集, p.22（1987） 